DOI: http://dx.doi.org/10.12775/ths.2016.003

\author{
Paolo Quintili \\ University of Rome «Tor Vergata» - Department of Literary and Philosophical Studies \\ Collège International de Philosophie - Paris \\ quintili@lettere.uniroma2.it
}

\title{
The Prehistory of Protolanguage's Notion. Condillac, Rousseau, De Brosses and the Origins of Language in the Eighteenth Century
}

\begin{abstract}
The famous prohibition of the Société de Linguistique de Paris, issued on March $8^{\text {th }}$, 1866, which forbade its members to submit research papers about the origin of language, reflected the mood of a precise historical and cultural situation. It was an affirmation of victory achieved by linguistic idealism and German historicis, formalized through an "edict" against the French naturalist-materialist tradition (or a European tradition tradition in general: for instance, in Italy, represented by Giambattista Vico). It was a victory against the philosophy of the Enlightenment, linked to the French Revolution. It was a political and ideological choice and an reflection of the intellectual climate of the Second Restoration, after 1848.

In fact, many various and interesting proposals were made in the eighteenth century by the Enlightenment thinkers on the subject of the origin of language. The approaches were empiricist and, at the time, they were meant to counter the theological clichés about the "divine" origins of the primordial language. This theological and metaphysical thesis was opposed by the Enlightenment with a naturalistic explanation. Therefore, those events mark the real prehistory of the protolanguage thesis, concerning human nature, being linked to natural modes of life of the "first men" and primitive humanity.

Our paper aims to investigate some of the most original philosophical versions concerning the prehistory of the notion of a protolanguage ${ }^{1}$, echoing the views of our
\end{abstract}

1 I apologize that I will not adopt the notion of protolanguage in its technical sense, but rather in a historical and descriptive sense. 
contemporary "gesturalists" (Condillac) and "vocalists" (Rousseau) or "verbalists" (De Brosses).

Keywords: preadamism; language action; linguistic naturalism; primitive language; materialism; language matter; materialist tradition; onomatopoeia.

\section{Preadamism, the thesis of Condillac and the " language of action"}

The most authoritative and significant initiator of the great debate about the origin of language in the modern age is Étienne Bonnot, Abbé de Condillac (1715-1780), who published his Essay on the Origin of Human Knowledge in 1746, which has recently appeared in a new edition in France, published by Vrin in 2014.

The Abbé devotes almost half of the essay to the matter, after all, Part II of the book is titled "The Language and Method" and contains a large section "The Origin and Progress of Language". This constitues an introduction to a historical process that will remain dormant until the late twentieth century, to finally return through the resumption of research on the topic officially banned in 1866 by a famous edict of the Société Linguistique de Paris.

Why the Linguistic Society issued the ban that prohibited the submission and publication of studies on the origin of language? At this time, during the age of Positivism and Idealism - the two dominant trends in European philosophy in the mid-nineteenth century - the matter of origins of language was a philosophical problem related to a certain past context. The age of Reformation and the Enlightenment in particular, gave rise to the controversies concerning the divine or "natural" beginnings of language ("divine" and "natural" were treated as synonyms) that flourished on the metaphysical grounds and were considered by the positivist linguists as nonscientific (theological, moral) content. The debate was primarily tied to the controversy of pre-adamism or the pre-adamic hypothesis. What was it? It was a heretical doctrine, dating back to ancient paganism, that advocated polygenism, i.e. the existence of several families of human species predating the so-called "family of Adam" from the Biblical story.

The mythical monogenic doctrine of the theological Catholic-Christian orthodoxy had been countered starting as early as the late antiquity up until the modern age by the heterodox philosophy of Giordano Bruno (15481600) (The expulsion of the triumphant Beast etc.), at the end of the sixteenth 
century. After Bruno, pre-Adamism or polygenism became an important issue found in the work of Isaac La Pereyre (1596-1670), who was the main representative of the idea at that time, and whose work had the following title: Praeadamitae sive Exercitatio super Versibus duodecimo, decimotertio, et decimoquarto, capitis quinti Epistulae D. Pauli ad Romanos, quibus inducuntur Primi Homines ante Adamum conditi, $1655 .^{2}$

What was the core of La Pereyre's thesis ? (Set aside the racist tendencies that pre-Adamism has taken later, in the nineteenth century). It was the claim that people have invented their first language, via different lines of development, under a particular condition imposed by the natural needs of intraspecific communication. Language is a tool imposed by, what will soon be called (by Rousseau in particular), the "state of nature" (état de nature), before or regardless of any divine intervention. Thus, humankind is not the heir to the original sin of Adam, with all the theological, cultural and intellectual consequences involved. We can resume La Pereyre's reasoning as follows: "If Adam sinned in a morally meaningful sense there must have been an Adamic law according to which he sinned. If law began with Adam, there must have been a lawless world before Adam, containing people" (Almond 1999: 53).

It is important to observe that almost all of the natural philosophy of the modern age and of the Enlightenment in particular, until the nineteenth century, is « preadamite» or polygenist. Therefore, we must locate the thesis and the debate on the origins of language within this ideological and cultural context, which also extends to other related issues, such as the origin and duration of the world, how old is the Earth etc. The preadamitic or primitive language belongs to a lawless world; and it is only with the advent of language that our laws can be determined.

In this context, too briefly traced, the position of Condillac is undoubtedly one of the most original. The abbot starts with the biblical account of the Genesis then he breaks off from it:

Adam and Eve did not owe the exercise of the operations of their soul to experience. As they came from the hands of God, they were able, by special assistance, to reflect and communicate their thoughts to each other. But I am assuming that two children, one of either sex, sometime after the deluge, had gotten lost in the desert before they would have known the use of any sign. The fact I have

2 La Pereyre, I. (2004). I Preadamiti/Praeadamitae (1655). Ed. by G. Lucchesini and P. Totaro. Macerata: Quodlibet. 
just stated gives me the right to make this assumption. Who can tell whether some nation owes its origin only to such an event? So that I am permitted to make the assumption. The question is to know how this budding nation made a language for itself (Condillac 2001: 113).

Therefore, the position taken by Condillac is that of Catholic-Christian monogenism. There are the sons of Noah, the continuation of the lineage of Adam, the first known to have the need for the use of language, those lost in the desert. The chapter is devoted to the topic of the nature of the first language that makes use of signs in order to enable one to act, it is entitled: "The language of action and that of articulated sounds considered from their point of origin". The question is: how to clarify what happened to people once they fell into their sinful condition, and thus, were forced to make use of signs, never previously having the need to use them because in the state of innocence people communicated their thoughts only by their mind (esprit). Therefore, the first requirement is to communicate a state of passion via the body, in a practically effective form - it will be the same need that J.-J. Rousseau (1712-1778) was to identify in his Essay on the Origin of Languages. People can communicate their passions only through precise, and always more precise, bodily attitudes, full of sense, which a receptor or an interlocutor can interpret, decrypt as signs. Condillac says:

When they lived together, they had occasion for greater exercise of these first operations, because their mutual discourse made them connect the cries of each passion to the perceptions of which they were the natural signs. They usually accompanied the cries with some movement, gesture, or action that made the expression more striking. For example, he who suffered by not having an object his needs demanded would not merely cry out; he made as if an effort to obtain it, moved his head, his arms, and all parts of his body. Moved by this display, the other fixed the eyes on the same object, and feeling his soul suffused with sentiments he was not yet able to account for to himself, he suffered by seeing the other suffer so miserably (Condillac 2001: 114).

As in the case of Rousseau, who is often too sharply contrasted with Condillac, the Abbé recognizes the "scream", that is the "cry of the passions", which arises from the needs as the first source of speech production. The emphasis placed on "pity", empathy, as we would say today, is very important to understand the pragmatic context in which we can place the theory of this "language of action". Condillac concludes: 
From this moment, he feels that he is eager to ease the other's pain, and he acts on this impression to the extent that it is within his ability. Thus by instinct alone these people asked for help and gave it. I say "by instinct alone", for reflection could not as yet have any share in it. One of them did not say, "I must bestir myself in that particular way to make the other understand what I need and to induce him to help me"; nor the other, "I see by his motions that he wants to have something and I intend to give it to him". But both acted as a result of the need that was most urgent for them (Condillac 2001: 114-115).

Body motions expressing passions, ranked in a finalistic way, make sense in a system of signs that gradually lose their initial vagueness and acquire conventional or arbitrary nature, typical of human language, through the use of memory :

Their memory began to have some exercise; they gained command of their imagination, and little by little, they succeeded I doing by reflection what they had formerly done only by instinct. In the beginning both made it a habit to recognize, by those signs, the sentiments, which the other felt at the moment; later they used those signs to communicate the sentiments they had experienced (Condillac 2001: 115).

The conclusion of Condillac's Essay is not far from the philosophical statement that will later be the main thesis of Rousseau: passions (fear, joy, sexual desire, hatred etc.) drive the process of development of the signssystem of a primitive language towards ever greater precision. Later, Condillac changes his ideas about this topic, with his Grammaire (1775), in accordance with the thesis about the analogy to and the imitation tools of natural language. ${ }^{3}$ Nevertheless, the main difference between Rousseau and Condillac is that, according to the latter, such a languageconsists, primarily (but not exclusively), of bodily actions and not of articulated sounds ${ }^{4}$.

3 See the notable work by Nobile (2012), chap. 2 : "Condillac change d'idée".

4 Condillac 2001: 115: «These details show how the cries of the passions contributed to the development of the operations of the mind by naturally originating the language of action, a language which in its early stages, conforming to the level of this couple's limited intelligence, consisted of mere contortions and agitated bodily movements». In a letter to his friend Cramer, a publisher, Condillac recognizes that cries are natural signs which can be confused, at a certain point along a spectrum, with arbitrary signs of a «protolanguage». He reproaches himself for putting too much emphasis on the difference between the two kinds of signs. 
This last view, the "vocalist" argument, will be the solution proposed a decade later, between 1754-1761, by Jean-Jacques Rousseau: the two hypotheses are not incompatible (Masataka 2008).

\section{The "vocalist" argument about the origin of language by Rousseau.}

The Essay on the Origin of Languages (1754, 1761, posthumous) is a work that Rousseau had never published in his lifetime. Initially conceived as a chapter for the second edition of? Discourse upon the origins and foundations of inequality among men (1753), the subject soon got out of his hand and acquired larger dimensions than just a chapter of the Discourse. The chapter became a book in itself, having various drafts and the most complete manuscript preserved in the Library of Neuchatel in Switzerland. The posthumous editions, starting from 1781, were all based on the text (Rousseau 1997).

For some years now, we have had an excellent critical version edited by Charles Porset, which was published in the Oeuvres completes de Rousseau. The anthology was released under the direction of R. Trousson and F. Eigeldinger on the occasion of the tercentenary of Rousseau's birthday in 2012. It is certain that this text has two points of reference or critical targets: $1 /$ theory of music and harmony by Jean-Philippe Rameau (1683-1764) (the Essay's subtitle is in fact: Wherein it's called about melody and musical imitation: Rousseau argues for the primacy of melody against the primacy of harmony accord); 2 / Condillac and the language of action. The content of the first four chapters of the Essay are "1. About the different Means to communicate our Thoughts". "2. That the first Invention of Speech derives not from Needs but from the Passions". "3. That the first Languages must have been Figurative". "4. On the distinctive Characteristics of the first Language and the Changes it must have undergone".Later in the Essay, Rousseau deals with different languages and the differences between them.

From the beginning of the Essay we can see the essential difference when compared to Condillac: there is no longer any reference to biblical stories. According to Rousseau: "the word (parole), which is the first social institution, owes its form only to natural causes. As soon as another man as a sentient and thinking being, like him, recognized one man, the desire or the need to share his feelings and thoughts made him to seek the means. And these means cannot be taken anywhere but from the senses, the only means by which a man can act on another man" (Rousseau 2012: 385). 
It is certain that Rousseau refers to the first section of the second part of Condillac's Essay when he says that the means by which a human can act on his or her kin by the senses are only two: movement and voice, i.e. sound. Movement can be direct, through touch, or indirect (mediated), through gesture. Sight and hearing are the two senses typical of a primitive language: "So only sight and hearing stay as passive organs of language among the dispersed men" (Rousseau 2012: 386). From these two modes of expression and communication Rousseau chooses to emphasize more the ones related to hearing, but he does acknowledge some sort of ontogenetic primacy of gesture and vision in the formation of the language capacity: "With so many beautiful grammars we do not understand more the symbols of the Egyptians. What the ancients said more clearly than ever, they not expressed in words but with signs. They did not say, but they showed (...) the object offered at the sight before speaking, shakes the imagination, excite the curiosity, keeps your mind on hold and waiting for what you are saying and will say" (Rousseau 2012: 389-391). Rousseau gives a long list of examples supporting these modes of primordial expression that pass through the medium of visual signs, before concluding with the words: "So, we talk much better by the eyes than by the ears" (Ibidem).

The Egyptian tongue, a very important matter, considered to be the oldest and the most primitive form of "Jews' language", has a long historical tradition of being viewed as the original language of people. Rousseau discovered this topic in the work of William Warburton (1698-1779), an English linguist and literary critic, who was the Bishop of Glouchester: The Divine Legation of Moses demonstrated on the principles of a Religion Deist, from the Omission of the Doctrine of a Future State of Rewards and Punishments in the Jewish Dispensation. In six books, 2 voll. London, 17371741. The book had been translated into French with the title: L'Essai sur les hiéroglyphes des Égyptiens, où l'on voit l'origine et le progrès du langage et de l'écriture, l'antiquité des sciences en Égypte, et l'origine du culte des animaux (french transl. by M.-A. L. de Malpeines, Paris, 1744). Notably, the same text had also inspired Condillac.

Nevertheless, is this a case of a real human "language" or is it rather a code, i.e. a system of abstract signs? Rousseau seems to adopt the latter approach, concluding: "But when it deals with the heart and to inflame the passions, this is another case entirely. The next impression of the speech that strikes with redoubled force provides some other emotion than the presence of the object, where at a glance you have seen it all (...). Let us conclude that visible signs convey a more precise imitation, but that interest is aroused more effectively by sounds. This makes me think that if we had 
never had anything but physical needs, we might very well never have spoken and would have understood one another perfectly by the language of gesture alone" (Rousseau 2000: 292).

On this last point, starting from the need to put in motion the sensitive machinery of typically human passions, Rousseau begins his analysis of the way that genuine human language originated by means of articulated sounds. The singing voice expresses the animal cry, le cri animal des passions: "It is therefore to be supposed that needs dictated the first gestures and that the passions wrested the first voices" (Rousseau 200: 293). Thus the first human languages were figurative, they appealed to passions rather than to needs and people "sang" these passions in a manner that was adapted to expressing, by voice, the different meanings associated with any particular affection. Rousseau has built the singing theory of the origin of speech:

We did not begin by reasoning but by feeling. It is claimed that men invented speech in order to express their needs; this opinion seems untenable to me. The natural effect of the first needs was to separate men and not to bring them together. This had to have been so for the species to spread and the earth to be populated promptly; otherwise, mankind would have been crammed into one corner of the world while the rest of it remained deserted. From this alone, it evidently follows that the origin of languages is not at all due to men's first needs; it would be absurd for the cause that separates them to come to be the means that unites them, from where, then, could be this origin derive? From the moral needs, the passions. The passions all bring men together, but the necessity of seeking their livelihood makes them flee one another. Neither hunger, nor thirst, but love, hatred, pity, anger wrested the first voices from them (Rousseau 2000: 293-294).

Here we come to the heart of Rousseau's thesis. ${ }^{5}$ The anthropological engine for the birth of human language is the expression of the fundamental passions. Voice conveys this expression more and more precisely, that is, the articulate voice: through song, singing, or at least, by melody. Rousseau's «preadamitic» or poligenistic belief is implicit here: he states that different human families have used different ways or figures to depict, through analogy made via articulated sounds, the primitive language of passions. The oldest languages in the world are those from Asia, the Chinese language in particular, Indian and lastly, as Warburton suggested, the Egyptian-Arab

5 See also some contemporary theses: Vaneechoutte \& Skoyles (1998); Cox (2001). 
ones. In Chapter IV, Rousseau describes the features that this ultimate "mother tongue" should have originally had. His reasoning is hypothetical:

As natural voices are unarticulated, words would have few articulations; a few interposed consonants eliminating the hiatus between the vowels would suffice to make them flowing and easy to pronounce. In contrast, its sounds would be quite varied, and the diversity of accents would multiply these same voices. Quantity and rhythm would provide further sources of combinations; in this way - since voices, sounds, accent, and number, which are from nature, would leave little to be done by articulations, which are conventional - one would sing it rather than speak it. Most of its root words would be imitative sounds, either of the accent of the passions, or of the effect of perceptible objects. Onomatopoeia would constantly make itself felt (Rousseau 2000: 295-296).

This recall that ends chapter IV goes back to an ancient source, the Cratylus by Plato, who proposed some, only seemingly, absurd theses:

This language would have many synonyms to express the same being in its different relations; it would have few adverbs and abstract words to express these same relations. It would have many augmentatives, diminutives, compound words; and expletive particles to give cadence to periods and roundness to phrases. It would have many irregularities and anomalies; it would neglect grammatical analogy to stick to the euphony, number, harmony, and beauty of sounds. Instead of arguments, it would have aphorisms; it would persuade without convincing, and depict without reasoning. It would resemble Chinese in certain respects, Greek in others, and Arabic in others. Develop these ideas in all their ramifications, and you will find Plato's Cratylus is not as ridiculous as it seems to be (Rousseau 2000: 296).

In conclusion, Rousseau's Essay is one of the greatest attempts, perhaps the most original one, at shaping a non-theological response to one of the most important issues that the Age of Enlightenment has bequeathed to the future ages, in particular, to our contemporary age. ${ }^{6}$

6 See Nobile (2012), chap. 3 (« Le paradoxe de la convention originaire») and chap. 4 («Retour à l'origine divine»). Thein, the author argues that it would be a theological issue also in Rousseau's Essay; but I think that we should consider, as well, the «vocalist argument» by Rousseau and his naturalist hypothesis grounded on the imitative theory of sign, which concerns just the origins of linguistic function in humans. We cannot confuse the doctrine 
After Rousseau, the topic of language origins plays the central role in Charles de Brosses's (1709-1777) Treatise on Mechanical Formation of Languages and Physical Principles of Etymology (vol. I, Paris, 1765, p. 195 ss.). This great linguist of the eighteenth century presents the "verbalist" thesis about the origins of language (discussed in the next chapter) at the beginning of a very important index of Chapter VI in the Treatise, entitled "About the primitive Language and Onomatopoeia". De Brosses analyzes the formation of terms, starting with a study of different roots of words via the physics of phonatory organs, hence the thesis of the oral, verbal origin of language.

\section{The "verbalist" argument about the origin of language by De Brosses. A materialistic point of view}

\subsection{The factory of words.}

In order to dismantle Rousseau's thesis, De Brosses, with his Traité de la formation mécanique des langues (De Brosses 1765), focuses on the "matter and form of language" rather than on the "philosophy of speech" (philosophie $d u$ discours). One can study the philosophie only after first investigating the two aspects of language: its matter and its form (Discours préliminaire, p. IV). Etymology is the focus of the Traité and it has to do, more than one would think, with logic: "C'est à les rapprocher tout à fait que ce Traité est destiné », says De Brosses : "L'étymologie tient, de plus près qu'on ne croit, à la logique : c'est à les rapprocher tout à fait que ce Traité est destiné » (p. v).

By the word "etymology" De Brosses does not mean the study of the origins as, literarily, the roots of words. He is interested in the mechanical and the physical study of the natural relationship between the means of linguistic expression through sound-i.e. voice and its physical mechanics - and the ideas (logic) establishing the sense of words that emerges over time:

On y remonte jusqu'aux premières causes, jusqu'aux principes élémentaires de l'expression des idées, par la formation des mots, afin d'en déduire avec plus de connaissances et de justesse les rapports et le degré de force que ceux-ci doivent avoir, lorsqu'ils sont rassemblés en troupes nombreuses (De Brosses 1765 : v-vj).

of Nicolas Beauzée (1717-1789), exposed in the article «Langue» from the Encyclopédie, with Rousseau's naturalistic theory of sign. See note 15. 
Here is the first condition, or the materialistic basis, of the origin of language: the primacy of "things" and their characters before "mind". A person can imitate and reproduce natural beings through voice in several ways:

Car on ne parvient à connaître la force du discours résultant de l'assemblage des termes, qu'autant qu'on a commencé par bien connaître la force des termes même, leur valeur réelle et primitive, leur acception conventionnelle et dérivée, qui ne s'est établie, bien ou mal à propos, que sur le véritable et premier sens physique du mot, que sur un rapport réel entre les termes, les choses et les idées (De Brosses 1765 : vj).

De Brosses defines here the ternary structure of the process of signification: 1) thing $\rightarrow$ 2) idea $\rightarrow$ 3) word. The author "limits himself" ( $s$ 'arrête) to the examination of this real, physical relationship. In this regard, he speaks about a "natural factory of words" (fabrique naturelle des mots):

Pour découvrir la source et le cours de quantité d'opinions répandues parmi les hommes, il a pris la voie d'en observer les fondements vrais ou faux dans la fabrique même des mots qu'ils ont inventés pour exprimer leurs idées dans l'assemblage et les nuances de couleurs qu'ils ont employées pour peindre aux autres hommes les objets de la nature, tels qu'ils les voyaient eux-mêmes (De Brosses 1765 : vij).

It is the importance of the study of etymologies as well as the focus on the roots of words and the phonetic rules that defines the system of language in its physical origins. De Brosses rejects the thesis about a common primitive language, specifically the Hebrew language, and shifts the axis of analysis onto the study of the roots of primitive words and the vocal organ. This is the true "langue primitive, organique, physique et nécessaire, commune à tout le genre humain":

Pour réussir à cette espèce d'analyse, il a fallu remonter jusqu'aux racines qui ont produit les mots usités dans le langage humain ; en découvrir le premier germe, et suivre ses développements de branches en branches ; observer comment et pourquoi ils on été produits tels qu'ils frappent notre oreille ; en un mot, arriver au dernier degré de l'analyse, aux principes les plus simples et vraiment primitifs (De Brosses 1765 : viij). 
As M. De Palo already states, ${ }^{7}$ according to Leibniz's theory about the non-arbitrariness of signs, the epistemological consequences, regarding the theory of the origin of language, are remarkable. Firstly, De Brosses maintains that words stem from «a small number of germs of speech or of common physical articulations» (pp. xi-xij), represented by types of phonetic movements producing sounds, resulting "absolutely" from the construction of the vocal organ, which the vocal organ can produce by its nature: ${ }^{8}$

Ces premières observations, fonde sur les principes physiques des choses, telles que la nature les a faites, amènent les conséquences suivantes $[\ldots]$. Que les germes étant en très petit nombre, l'intelligence ne peut faire autre chose que de les répéter, de les assembler, de les combiner de toutes les manières possibles pour fabriquer les mots tant primitifs que dérivés, et tout l'appareil du langage. Que, dans ce petit nombre de germes ou d'articulation, le choix de celle qu'on veut faire servir à la fabrique d'un mot, c'està-dire au nom d'un objet réel, est physiquement déterminé par la nature et par la qualité de l'objet même, de manière a dépeindre, autant qu'il est possible, l'objet tel qu'il est, sans quoi le mot n'en donnerait aucune idée : tellement que l'homme, qui sera dans le cas d'imposer le premier nom à une chose rude, emploiera une inflexion rude et non pas une inflexion douce; de même qu'entre les sept couleurs primitives, un peintre, qui veut peindre l'herbe, est obligé d'employer le vert et non pas le violet (De Brosses 1765 : xij-xiij).

Secondly, De Brosses concludes, on the one hand, that words were neither arbitrary nor conventional in their origins; on the other hand, that language differences depend on the different ways in which primitive humans manipulated the idea-thing-word relationship. The problem of onomatopoeia, in this case, is one of the main topics of the Traité. In this sense, De Brosses states a principle that accounts, genetically, for the natural origin of the arbitrariness of the sign: in its capacity for imitating and interpreting things. It is the main account of the Traité :

De Palo (2005, 92-100): «3. La lingua primitiva».

8 See Nobile (2007a : 111) : «Le matérialisme naturaliste et historico-cognitif du Traité est sans doute une des expressions les plus ambitieuses et les plus cohérentes de l'esprit des Lumières sur le terrain linguistique. Bien plus que le cartésianisme théologique d'un Beauzée, il impose aux études linguistiques un paradigme nouveau, laïque et 'physique', celui du mimétisme phonétique, qui ouvre la possibilité même d'une science du langage». 
Le système de la première fabrique du langage humain et de l'imposition des noms aux choses n'est donc pas arbitraire et conventionnel, comme on coutume de se le figurer ; mais un vrai système de nécessité déterminée par deux causes. L'une est la construction des organes vocaux qui ne peuvent rendre que certains sons analogues à leur structure ; l'autre est la nature et la propriété des choses réelles qu'on veut nommer. Elle oblige d'employer à leur nom des sons qui les dépeignent, en établissant entre la chose et le mot un rapport par lequel le mot puisse exciter une idée de la chose. Que la première fabrique du langage humain n'a pu consister, comme l'expérience et les observations le démontrent, qu'en une peinture plus ou moins complète des choses nommées; telle qu'il était possible aux organes vocaux de l'effectuer par un bruit imitatif des objets réels. Que cette peinture imitative s'est étendue de degrés en degrés, de nuances en nuances, par tous les moyens possibles, bons ou mauvais, depuis les noms des choses les plus susceptibles d'être imitées par le son vocal, jusqu'aux noms des choses qui le sont le moins ; et que toute la propagation du langage s'est faite, de manière ou d'autre, sur ce premier plan d'imitation dicté par la nature ; ainsi que l'expérience et les observations le prouvent encore. Que les choses étant ainsi, il existe une langue primitive, organique, physique et nécessaire, commune à tout le genre humain (De Brosses 1765 : xiij-xv).

The procedure adopted by De Brosses in the semantic study of linguistic signs submits the question of origin to an analysis that is ontologically and methodologically naturalistic and deductive:

Après être remonté aux premiers principes du langage, tires de l'organisation humaine, et de la propriété des choses nommées, il est important et convenable de redescendre au développement de ces principes; d'observer les effets de la dérivation, après avoir connu ses causes et ses éléments ; d'examiner par quelles voies elle a passé du physique au moral, et du matériel à l'intellectuel ; de démêler, par l'analyse des opérations successives, l'empire ou l'influence de la nature dans le mécanisme de la parole et de la formation des mots, d'avec ce que l'homme y a mis d'arbitraire par son propre choix, par l'usage, par la convention reçue ; de montrer par quelles déterminations, par quelles méthodes, et jusqu'à quel point l'arbitraire a travaillé sur le premier fond physiquement nécessairement donné par la nature. (De Brosses 1765: xix-xx). 
The index of vol. I of the Treatise provides an overall idea behind De Brosses's research:

Table des chapitres du vol. I

Chap. I. Plan général de cet Ouvrage. Que l'art étymologique n'est pas un art inutile ni incertain, p. 1-34.

Chap. II. Utilité qu'on peut retirer de l'art étymologique pour les autres sciences, pp. 35-99.

Chap. III. De l'organe de la voix \& de l'opération de chacune des parties qui le composent, pp. 100-152.

Chap. IV. De la voix nasale \& de l'organe du chant

Chap. V. De l'alphabet organique \& universel composé d'une voyelle \& de six consonnes, pp. 177-194.

Chap. VI. De la langue primitive \& de l'onomatopée, pp. 195-294

[The most important chapter].

Chap. VII. De l'écriture numérale par chiffres, pp. 463.

Therefore, De Brosses has the intention of connecting, in his Traité, the historical and cultural origins of language with its natural and material origins. There is no discontinuation between nature and history or culture. ${ }^{9}$

\subsection{Theoretical points acquired by De Brosses about the problem of the origin of language}

Finally, De Brosses reaches a series of key-points concerning the origin of human language that we summarize in nine theoretical acquisitions or «theses» about the materialistic and naturalistic theory of sign: ${ }^{10}$

First / The evolutionary-dynamic character of language in general.

This evolution, next, compared to the origin before the unknowable, unfolds «from the physical to the moral», from low levels to the high ones, without any discontinuations.

9 See the interesting account by Nobile (2007b: 513-514): « The thesis of naturalhistorical origin of language has opened the logical space of prehistory, in which the reconstruction of the Indoeuropean language finds its place».

10 See De Palo (2005: 89-90), for the materialistic (and vitalistic) meaning of mécanique and mécanisme; see also Pellegrino (2013: 40-79), chap. 2: "Charles De Brosses linguista». 
Second/ The naturalization of the concept of «primitive common language».

De Brosses dissociates the existence of an "Adamic language" guaranteed by faith: God has given us the primitive language, but it remains unknown - from the secondary origin of knowledge, tied to a conjectural genesis, abstract yet natural: the distinction between noumenon and a linguistic phenomenon. We may interpret this point of De Brosses's theory in terms of a "phenomenal reduction": science, starting with the physical appearance of words studies only the mechanical phenomena and the formation of languages.

Third/ The physical etymology reaches, and has to reach, the level of thought.

This is the project behind the Traité: an entire chapter is devoted to analyzing the utility of etymology for the physics of ideas. Nevertheless, the understanding of thought is not the focalization of an abstract form that determines the necessary conditions for truth; on the contrary, it is the concrete, real thinking, with the physical properties of the linguistic contents of thought.

Fourth/ De Brosses postulates only one natural language.

That is, a non-arbitrary language, made up of sounds and shapes that pictorially mimicthings themselves.

Fifth/ Linguistic atomism.

Word-sound, idea, object - these are distinct and well-defined beings which exist independently of each other. This is a continuistic option: the signification process breaks the vowel continuum. There is one fundamental voice with six articulating consonants. The original matter of language is sound and its natural articulations.

Sixth/ The mechanics of languages (mécanique des langues): it already stands in opposition to another approach that seeks the object/language as an autonomous body.

Language (langue), an object itself, is opposed to grammar (grammaire) as the Cartesian study of the basic communicative elements of langues (plural). De Brosses does not postulate an independent object-language.

Seventh/ The first definition of a «universal phonetic alphabet».

It is a "reasoned dictionary" - like the contemporary Encyclopédie, ou Dictionnaire raisonné des sciences, des arts et des métiers (1751-1772) by D. Diderot (1713-1784) - of the possible expressive articulations of the 
very matter of the original language. De Brosses calls for a reductionist and naturalistic intention.

Eighth/Focus on the genesis/history of language dichotomy, but without a gap between them (cassure).

The primitive language, articulated in a second genesis, gives way to a universal archeology of language that functions as a code which allows deciphering the history of human expressive function in general (Condorcet, La Langue Universelle. Fragment inédit $\left.{ }^{11}\right)$.

Ninth/ A natural concept of language (langue).

Language (langue) is not and should never become a theoretical concept for De Brosses. The speaker's intuitive consciousness, natural and historical, gives a language its identity. The evolution of language depends on the physical necessity and the natural contingency of phonetic change, for which a linguist must trace the hypothetical cognitive needs.

Returning to the question of origins, De Brosses, on the one hand, legitimates his own work by drawing on the (orthodox) idea of a primitive "Adamic language», the existence of which is guaranteed by faith; on the other hand, in the Traité, he deals with the epistemological question of the secondary origin of language attributed to Humans themselves. This question becomes again ontological because De Brosses upholds the natural and necessary genesis of language as the only knowable origin and, therefore, the only possible origin of human communication. The Adamic language becomes a sort of linguistic noumenon, the unknowable, in which we must believe relying on faith: we do not know or need to know anything about it. The secondary genesis of language remains, likewise, dependent on the origin and the mechanic formation of natural languages, the only ones that concerns a philosopher of language.

Finally, I would invoke here the thesis suggested by S. Auroux (1979: $60)$, who underlines that

Pour les Lumières, le mot est un son signe d'une idée représentant les objets ou leurs propriétés; ces trois êtres possèdent chacun une existence indépendante et parfaitement hétérogène à celle des deux autres. Dès lors surgit un problème que le président De Brosses formule clairement : «(l'usage de la parole) consiste à rendre par

$11 \quad$ See Granger (1954 : 197-219). 
la voix ce que l'âme a reçu par les sens, à représenter de nouveau au-dehors ce qui est au-dedans et qui y était déjà venu du dehors (...). Comment l'être réel, l'idée, le son et la lettre, quatre choses de nature si opposée, et qui paraissent si peu conciliables, se sontelles ainsi rapprochées ?». On ne peut répondre à cette question qu'en étudiant l'origine des langues comme formation du signe linguistique. Dans l'hétérogénéité des êtres donnant naissance au signe est d'emblée inscrite la nécessité d'avoir à comprendre son arbitraire, c'est-à-dire précisément cette hétérogénéité. C'est parce que le mot n'est pas appréhendé comme unité indissoluble, mais comme un assemblage de constituants, que son origine doit être conçue. La détermination fondamentale de la problématique de l'origine des langues, c'est en quelque sorte l'indépendance et la contingence des éléments du langage.

I would add an important complement to this analysis by Auroux, namely, that the main intellectual heritage of the $18^{\text {th }}$ century's materialism J. Meslier, J.O. La Mettrie, P. H. Th. D’Holbach, D. Diderot and, last, De Brosses (Quintili 2001 \& 2009) - was the independence and the contingencynecessity of linguistic elements, linked to the materialistic premises, both ontological and methodological. Materialism conceives language as a specific product of the human nature. Therefore, "arbitrariness" rests originally on the human «interpretation» of Dame Nature's laws, common to all natural entities, from amoeba to homo sapiens.

Finally, we can derive from this survey a retrospective theoretical consideration. The materialistic approach comes into conflict with Saussure's structural approach, according to which, the elements, i.e. «the object-terms alone[,] do not involve meaning: the elementary meaningful units can be found at the level of structures and not at the level of elements» (Greimas 1966). In the same vein, Ferdinand de Saussure states:

Dans l'intérieur d'une même langue, tous les mots qui expriment des idées voisines se limitent réciproquement. (1997: 160)

However, mature linguistic materialism, which refers to the ideal tradition, stands in opposition to Saussure's statement: “The Only Materialist Tradition" (L. Althusser ${ }^{12}$ ) - e.g. in the approach of F. Ferretti (1997 \& 2010), as in the main historical teaching of De Brosses (1765). The significant role of the basic elements of language, in their natural origins, becomes the starting

12 It is the title of the last unfinished work of Louis Althusser (1993). 
point for an appropriate assessment of the process of signification; see for instance the issue of phono-symbolism (Nobile \& Lombardi Vallauri 2016). That is why the problem of the origins of language, i.e. the physical and historical origins, still is, in this perspective, of central importance.

\section{References}

Almond, Ph. C. (1999). Adam and Eve in Seventeenth-Century Thought. Cambridge: Cambridge University Press.

Althusser, L. (1993). L’Unique Tradition Matérialiste. Lignes, n 18, 72-119. Paris : Éditions Hazan.

Auroux, S. (1979). La sémiotique des encyclopédistes. Paris: Payot.

Condillac, E.-B. de (2001). Essay on the Origin of Human Knowledge. Ed. by H. Aarsleff. Cambridge: Cambridge University Press.

Cox, A. (2001). The Mimetic Hypothesis and Embodied Musical Meaning. Musicae Scientiae Fall, vol.5, 2, 195-212.

De Brosses, Ch., le Président (1765). Traité de la formation mécanique des langues et des principes physiques de l'étymologie. 2 vol. Paris: Saillant Vincent et Desaint.

De Palo, M. (2005). De Brosses e Leibniz : un modello di naturalismo linguistico. In S. Gensini (Ed.), Linguaggio, mente e conoscenza. Intorno a Leibniz (pp. 87-120). Rome: Carocci.

De Saussure, F. (1997). Cours de linguistique générale. Publié par Ch. Bailly et A. Séchehaye, avec la collaboration de A. Riedlinger, éd. critique préparée par T. de Mauro, Postface de L.-J. Calvet. Paris : Payot.

Ferretti, F. (1997). Le immagini mentali nelle scienze cognitive. Rome: Carocci.

Ferreti, F. (2010). Alle origine del linguaggio umano. Il punto di vista evoluzionistico. Rome-Bari : Laterza, 2010. French edition (2015): Aux origines $d u$ langage humain. Le point de vue évolutionniste, translated by. P. Quintili \& M. Tascherio. Paris : L'Harmattan.

Greimas, A. J. (1966). Sémantique Structurale. Recherche de méthode. Paris : Larousse.

Granger, G. G. (1954). Langue universelle et formalisation des sciences. Un fragment inédit de Condorcet, Revue d'histoire des sciences et de leurs applications, vol 7(3), 197-219 [http://www.persee.fr/doc/rhs_0048-7996_1954_ num_7_3_3437].

Masataka, N. (2008). The Gestural Theory and the Vocal Theory of Language Origins are not Incompatible with one another. In N. Masataka (Ed.), The Origins of Language, 1-10. New York : Springer.

Nobile, L. (2007a). De Brosses, Jakobson et l'ontogenèse phonologique. Histoire Epistémologie Langage, 29/I, 105-114. 
Nobile, L. (2007b). De Brosses e Cesarotti. Origine delle lingue e origini della linguistica nell'età della rivoluzione politica. In V. Della Valle \& P. Trifone (Eds.), Studi linguistici per Luca Serianni , 507-521. Rome: Salerno.

Nobile, L. (2012). La Grammaire de Condillac face au paradoxe de l'origine naturelle du langage. In B. Colombat, J.-M. Fournier, V. Raby (Eds.), Vers une histoire générale de la grammaire française (pp. 151-168). Paris : Honoré Champion.

Nobile, L., Lombardi Vallauri, E. (2016). Onomatopea e fonosimbolismo. Rome: Carocci.

Pellegrino, R. (2013). Viaggio, scrittura e senso nell'opera di Charles De Brosses. Napoli : ESI.

Quintili, P. (2001). La pensée critique de Diderot. Matérialisme, science et poésie à l'âge de l'Encyclopédie. 1742-1782. Paris : Honoré Champion.

Quintili, P. (2009). Matérialismes et Lumières. Philosophies de la vie, autour de Diderot et de quelques autres. 1706-1789. Paris : Honoré Champion.

Rousseau, J.-J. (1997). Essai sur l'origine des langues. Fac-simile du manuscrit de Neuchâtel. Introduction de J. Starobinski et notice historique de F. S. Eigeldinger. Paris : Honoré Champion.

Rousseau, J.-J. (2000). Essay on the Origin of languages. In J.-J. Rousseau, The Collected Writings of Rousseau. Vol. 7. Ed. by J. T. Scott. Hanover and London: University Press of New England.

Rousseau, J.-J. (2012). Essai sur l'origine des langues, où il est parlé de la mélodie et de l'imitation musicale. In J.-J. Rousseau, Euvres complètes. Vol. XII. Paris : Honoré Champion.

Vaneechoutte, M., Skoyles, J.R. (1998). The memetic origin of language: modern humans as musical primates. Journal of Memetics - Evolutionary Models of Information Transmission, 2, http://cfpm.org/jom-emit/1998/vol2/ vaneechoutte_m\&skoyles_jr.html. 